\title{
Differential Roles of 5-HT Receptor Subtypes in Cue and Cocaine Reinstatement of Cocaine-Seeking Behavior in Rats
}

\author{
Jeffrey J Burmeister', Erin M Lungren', Kenneth F Kirschner' and Janet L Neisewander*,' \\ 'Department of Psychology, Arizona State University, Tempe, AZ, USA
}

\begin{abstract}
The 5-HT indirect agonist, $d$-fenfluramine, attenuates cue reinstatement of extinguished cocaine-seeking behavior. To investigate the role of $5-\mathrm{HT}$ receptor subtypes in this effect, we examined whether the attenuation is reversed by either a $5-\mathrm{HT}_{1 \mathrm{~A}}, 5-\mathrm{HT}_{2} \mathrm{~A} / \mathrm{C}$, or $5-\mathrm{HT}_{2} \mathrm{C}$ receptor antagonist. We also examined the effects of the antagonists alone on both cue and cocaine-primed reinstatement. Rats that had been trained to press a lever for cocaine $(0.75 \mathrm{mg} / \mathrm{kg} / 0.1 \mathrm{ml}$, i.v. $)$ paired with light and tone cues underwent daily extinction sessions during which responding had no consequences. We then examined the effects of WAY 100635 (0-1.0 mg/kg, s.c.), ketanserin (0-10.0 mg/kg, i.p.), or SB 242,084 (0-1.0 mg/kg, i.p.) with and without d-fenfluramine (1.0 mg/kg, i.p.) pretreatment on cue reinstatement. Subsequently, we examined the effects of the antagonists on cocaine-primed (7.5 or $15.0 \mathrm{mg} / \mathrm{kg}$, i.p.) reinstatement. The $5-\mathrm{HT}_{\text {IA }}$ antagonist, WAY 100635, failed to alter cue reinstatement, but attenuated cocaine reinstatement. Conversely, the 5- $\mathrm{HT}_{2 \mathrm{~A} / \mathrm{C}}$ antagonist, ketanserin, attenuated cue reinstatement, but failed to alter cocaine reinstatement. The $5-\mathrm{HT}_{2} \mathrm{C}$-selective antagonist, SB 242,084, did not alter cue or cocaine reinstatement, but was the only drug that reversed the $d$-fenfluramine-induced attenuation of cue reinstatement. The findings suggest that stimulation of 5-HTIA receptors plays a critical role in cocaine-primed, but not cue, reinstatement. Furthermore, $5-\mathrm{HT}_{2 \mathrm{~A}}$ and $5-\mathrm{HT}_{2 \mathrm{C}}$ receptors may play oppositional roles in cue reinstatement. The SB 242,084 reversal of the $d$-fenfluramine attenuation suggests that stimulation of $5-\mathrm{HT}_{2} \mathrm{C}$ receptors inhibits cue reinstatement, whereas the ketanserin-induced attenuation of cue reinstatement suggests that decreased stimulation of $5-\mathrm{HT}_{2 \mathrm{~A}}$ receptors inhibits this behavior.

Neuropsychopharmacology (2004) 29, 660-668, advance online publication, 12 November 2003; doi: | 0.1038/sj.npp. I 300346
\end{abstract}

Keywords: conditioned reinforcement; extinction; incentive motivation; 5- $\mathrm{HT}_{1 \mathrm{~A}}$ receptors; $5-\mathrm{HT}_{2 \mathrm{C}}$ receptors; 5- $\mathrm{HT}_{2 \mathrm{~A}}$ receptors

\section{INTRODUCTION}

In humans, cocaine and cocaine-associated stimuli can elicit incentive motivation for cocaine that may manifest as craving and may contribute to maintenance and relapse of cocaine abuse (Jaffe et al, 1989; Wallace, 1989; Rohsenow et al, 1991; Ehrman et al, 1992). Incentive motivation for cocaine can be studied in animals using the extinction/ reinstatement model (de Wit and Stewart, 1981; Markou et al, 1993; Fuchs et al, 1998). In this model, animals that have been trained to press a lever for cocaine reinforcement subsequently undergo extinction during which responses have no scheduled consequences. Rats are then tested for reinstatement of extinguished cocaine-seeking behavior (ie operant responding in the absence of cocaine reinforcement) elicited by cocaine-conditioned stimuli or cocaine priming. Reinstatement of cocaine-seeking behavior is

*Correspondence: JL Neisewander, Department of Psychology, Arizona State University, PO Box 87II 04, Tempe, AZ 85287-I I04, USA, Tel: + I (480) 965 0209, Fax: + I (480) 9658544 ,

E-mail: janet.neisewander@asu.edu

Received 07 May 2003; revised 21 September 2003; accepted 06 October 2003

Online publication: 9 October 2003 at http://www.acnp.org/citations/ Npp I0090303203/default.pdf believed to measure incentive motivation for cocaine elicited by these stimuli (Stewart, 1983; Robinson and Berridge, 1993).

The role of 5-HT neurotransmission in reinstatement of cocaine-seeking behavior is unclear and may vary depending on whether cues or cocaine are used to reinstate cocaine-seeking behavior. Manipulations that decrease 5HT neurotransmission attenuate cue-elicited reinstatement of cocaine-seeking behavior, but enhance cocaine-primed reinstatement of cocaine-seeking behavior (Tran-Nguyen et al, 1999, 2001). Paradoxically, manipulations that increase 5-HT neurotransmission, such as the indirect agonists fluoxetine or $d$-fenfluramine, also attenuate cueelicited reinstatement of cocaine-seeking behavior, but do not reliably alter cocaine-primed reinstatement of cocaineseeking behavior (Baker et al, 2001; Burmeister et al, 2003). The nonselective $5-\mathrm{HT}_{2}$ receptor antagonist, ritanserin, fails to alter cocaine-primed reinstatement of cocaine-seeking behavior (Schenk, 2000); however, more selective $5-\mathrm{HT}_{2}$ receptor antagonists have provided opposing results. Specifically, the $5-\mathrm{HT}_{2 \mathrm{C}}$ receptor antagonist, SB 242,084, enhances cocaine-primed reinstatement of cocaine-seeking behavior, whereas the $5-\mathrm{HT}_{2 \mathrm{~A}}$ receptor antagonist, MDL 100907, attenuates cocaine-primed reinstatement (Fletcher et al, 2002a). The $5-\mathrm{HT}_{1 \mathrm{~A}}$ receptor antagonist, WAY 100635, 
also attenuates cocaine-primed reinstatement (Schenk, 2000), but has no effect on cue reinstatement of cocaineseeking behavior (Cervo et al, 2003). The effects of $5-\mathrm{HT}_{2}$ receptor antagonists on cue-elicited reinstatement have not been reported previously.

The present study examined the effects of WAY 100635, ketanserin, and SB 242,084, 5- $\mathrm{HT}_{1 \mathrm{~A}}, 5-\mathrm{HT}_{2 \mathrm{~A} / \mathrm{C}}$, and $5-\mathrm{HT}_{2 \mathrm{C}}$ receptor antagonists, respectively, on reinstatement of cocaine-seeking behavior by cocaine-paired cues or cocaine priming injections. The present study also examined whether the respective antagonists could reverse the $d$-fenfluramine-induced attenuation of cue-elicited reinstatement that we reported previously (Burmeister et al, 2003).

\section{MATERIALS AND METHODS}

\section{Drugs}

Ketanserin, WAY 100635, and $d$-fenfluramine (Sigma Chemical Co., St Louis, MO) were dissolved in bacteriostatic saline. SB 242,084 (Sigma Chemical Co.) was prepared fresh for each test in bacteriostatic saline containing $8 \%$ hydroxypropyl- $\beta$-cyclodextrin (Sigma Chemical Co.) and $25 \mathrm{mM}$ citric acid (Sigma Chemical Co.). Respective vehicle solutions were administered to controls (ie $0.0 \mathrm{mg} / \mathrm{kg}$ dose) and injections were administered at a volume of $1 \mathrm{ml} / \mathrm{kg}$. Cocaine hydrochloride was obtained from RTI International (Research Triangle Park, NC) and was dissolved in bacteriostatic saline and filtered through a $0.2 \mu \mathrm{m}$ filter.

\section{Animals}

Male Sprague-Dawley rats weighing 250-325 g at the start of the experiments were individually housed in a climatecontrolled colony room with a 12-h reversed light/dark cycle (lights off at 0600). Housing facilities and care of the animals were in accordance with the conditions set forth in the 'Guide for the Care and Use of Laboratory Animals' (Institute of Laboratory Animal Resources on Life Sciences, National Research Council 1996).

\section{Surgery}

Animals were handled at least 6 days prior to surgery. Implantation of intravenous catheters with head mounts was performed under anesthesia with sodium pentobarbital (50 mg/kg, i.p.; Sigma Chemical Co.) administered $5 \mathrm{~min}$ after pretreatment with atropine sulfate $(10 \mathrm{mg} / \mathrm{kg}$, i.p.; Sigma Chemical Co.). Surgical procedures were performed as described by Neisewander et al (2000). Catheter patency was maintained by daily flushing with a solution of $0.1 \mathrm{ml}$ bacteriostatic saline containing heparin sodium $(10 \mathrm{U} / \mathrm{ml}$; Elkins-Sinn Inc., Cherry Hill, NJ), streptokinase $(0.67 \mathrm{mg} /$ $\mathrm{ml}$; Astra USA, Inc., Westerborough, MA), and ticarcillin disodium $(66.7 \mathrm{mg} / \mathrm{ml}$; SmithKline Beecham Pharmaceuticals, Philadelphia, PA). Proper catheter functioning was verified periodically throughout the experiments by intravenous administration of $0.03-0.05 \mathrm{ml}$ methohexital sodium (16.6 mg/m; Jones Pharma Inc., St Louis, MO), a dose sufficient to briefly anesthetize the animal only when administered i.v. The rats were allowed at least 5 days recovery before the initiation of self-administration training.

\section{Self-Administration Training}

Cocaine self-administration training took place in operant conditioning chambers $(28 \times 10 \times 20 \mathrm{~cm}$; Med Associates, St Albans, VT) equipped with an active and an inactive lever, a cue light $4 \mathrm{~cm}$ above the active lever, a tone generator $(500 \mathrm{~Hz}, 10 \mathrm{~dB}$ above ground noise) and a house light located opposite the levers. Each operant conditioning chamber was housed within a larger ventilated soundattenuating chamber. Infusion pumps (Med Associates) were connected to liquid swivels (Instech, Plymouth Meeting, PA) located above the chambers. The swivels were fastened to the catheters via polyethylene 20 tubing encased inside a metal spring leash (Plastics One, Roanoke, VA).

Cocaine self-administration training consisted of 18-28 daily, 2-h sessions during which rats were trained to press the active lever to obtain a cocaine infusion $(0.75 \mathrm{mg} / \mathrm{kg} /$ $0.1 \mathrm{ml}$, i.v.). Training sessions took place during the animals' dark cycle. To facilitate acquisition of cocaine self-administration (Carroll et al, 1981), animals were initially restricted to $15-20 \mathrm{~g}$ of food/day beginning 2 days prior to training. They remained food restricted until they met a criterion of seven infusions/hour on a fixed-ratio (FR) 1 schedule of cocaine reinforcement for at least 3 days. After animals reached this criterion, they were then given access to food ad libitum in the home cage throughout the remainder of the experiment. Animals progressed from an FR 1 to a variable-ratio (VR) 2 and then a VR 5 schedule of reinforcement. All rats received a minimum of five sessions on each schedule. Schedule completions on the active lever resulted in simultaneous activation of the house light, cue light and tone generator, followed $1 \mathrm{~s}$ later by activation of the infusion pump. The $0.1 \mathrm{ml}$ cocaine infusion was delivered over a 6-s period, after which the cue light, tone, and pump were inactivated simultaneously. The house light remained activated for a 20-s timeout period, during which lever presses had no scheduled consequences. Responses on the inactive lever had no scheduled consequences. No cocaine priming infusions were given during training.

\section{Extinction Training}

Extinction training began the day after self-administration training was completed. Extinction training consisted of 1-h exposures to the self-administration environment across 21-28 consecutive days. During this time, active and inactive lever presses were recorded but had no scheduled consequences (ie did not activate the cocaine infusion pump or cocaine-paired stimuli). Extinction training continued for a minimum of 21 days or until response rates declined to less than 20 responses/h.

\section{Cue Reinstatement Testing}

Following extinction training, all animals in this study underwent testing for cue reinstatement on 2 separate days in order to test the effects of the antagonists alone and in combination with $d$-fenfluramine pretreatment. Separate groups of animals were used to test the effects of each 
antagonist (total $N=134$ ). Rats within each of the antagonist experiments were assigned to groups that received an assigned dose of either WAY $100635(0.0,0.1$, 0.3 , or $1.0 \mathrm{mg} / \mathrm{kg}$, s.c.; $N=7-8)$, ketanserin $(0.0,0.3,1.0,3.0$, or $10.0 \mathrm{mg} / \mathrm{kg}$, i.p.; $N=10-13)$, or SB $242,084(0.0,0.1,0.3$, or $1.0 \mathrm{mg} / \mathrm{kg}$, i.p.; $N=11-13$ ) 30,45 , or $30 \mathrm{~min}$ prior to each test, respectively. Assignment to dosage groups was counterbalanced for previous cocaine intake. All of the rats then received another pretreatment $15 \mathrm{~min}$ before testing; on one of the test days they received saline and on the other test day they received $d$-fenfluramine $(1.0 \mathrm{mg} / \mathrm{kg}$, i.p. $)$, with order of the two conditions counterbalanced. The preadministration intervals were chosen based on previous studies examining cocaine-mediated behaviors (Schenk, 2000; Fletcher et al, 2002a; Munzar et al, 2002; Burmeister et al, 2003). To initiate testing, one passive presentation of the cocaine-paired stimulus complex (ie lights, tone, and pump motor) was given. During the remaining 1 -h test session, responses on the active lever were reinforced by presentation of the cocaine-paired stimulus complex using an FR 1 schedule. Responses on the active and inactive levers were recorded throughout the 1 -h session and the former was used as a measure of cocaine-seeking behavior. The FR 1 schedule was used in place of the VR 5 training schedule because responding for the conditioned stimuli is not maintained on a VR 5 schedule (unpublished observation). Animals were given 4-12 extinction training sessions between the tests to allow extinction baseline response rates to restabilize. The response rate during the extinction session immediately preceding the test days was used as a baseline for cue reinstatement.

\section{Cocaine Reinstatement Testing}

After the two cue reinstatement tests, most of the animals were tested two additional times for cocaine-primed reinstatement of cocaine-seeking behavior. These animals received two to six additional 1 -h extinction sessions before their first test. Animals were pretreated with the same antagonist as they had received prior to cue reinstatement tests, with dosage groups recounterbalanced for cocaineintake as well as antagonist dose received during cue reinstatement. The doses and preadministration times were the same as those used for cue reinstatement testing. A saline prime was administered immediately before the extinction session on the day preceding each of the cocaine reinstatement tests. The response rate during this session was used as a baseline for cocaine reinstatement tests. Rats were administered the cocaine prime immediately prior to the 1 -h test period. In the first experiment, WAY 100635 produced a robust decrease in cocaine-seeking behavior after the $15 \mathrm{mg} / \mathrm{kg}$, i.p. cocaine prime, and therefore, no further testing was conducted. In the second experiment, ketanserin failed to alter cocaine-seeking behavior after the $15 \mathrm{mg} / \mathrm{kg}$, i.p. cocaine prime, and therefore, a lower priming dose of $7.5 \mathrm{mg} / \mathrm{kg}$, i.p. was examined subsequently. In the third experiment, the $7.5 \mathrm{mg} / \mathrm{kg}$ i.p. priming dose was examined first to enhance sensitivity for detecting a possible enhancement of cocaine reinstatement by SB 242,084 as found in a previous study (Fletcher et al, 2002a). Since SB 242,084 failed to alter cocaine reinstatement at this dose, we subsequently examined the effects of SB 242,084 on reinstatement by a $15 \mathrm{mg} / \mathrm{kg}$, i.p. prime. In the latter two experiments, animals received four to five daily 1 -h extinction sessions between the two cocaine-primed reinstatement tests. During testing, responses had no scheduled consequences.

\section{Locomotor Activity Testing}

Due to a ketanserin-induced increase in response latency observed during cue reinstatement, its effects on locomotor activity were examined to assess whether ketanserin produced a general behavioral disruption. After ketanserin-treated rats had completed all of the tests for cocaineseeking behavior, they were assigned to groups, counterbalanced for previous ketanserin drug history, that received $0.0,1.0$, or $10.0 \mathrm{mg} / \mathrm{kg}$, i.p. $(N=5-8)$. At $45 \mathrm{~min}$ after ketanserin administration, the rats were placed into Plexiglas cages $(44 \times 24 \times 20 \mathrm{~cm}$ high $)$ for $60 \mathrm{~min}$. The cages were equipped with a wire-bar floor, a perforated metal lid, and two sets of computer-automated photocells located $32 \mathrm{~cm}$ apart and $4 \mathrm{~cm}$ above the cage floor which recorded the number of times the rats moved from one end of the cage to the other (ie crosses).

\section{STATISTICAL ANALYSIS}

Cocaine intake, baseline responses, response latency, and locomotor activity were analyzed separately for each experiment using one-way ANOVAs with dosage group as a between-subjects factor. For cue reinstatement in each experiment, responses/hour during the reinstatement test session were analyzed using mixed factor ANOVAs with saline $v s d$-fenfluramine as a within-subjects factor and dose of antagonist as a between-subjects factor. Significant interactions were further analyzed using separate one-way ANOVAs of the saline $v s d$-fenfluramine test days with dose as a factor. For cocaine reinstatement, responses/hour were analyzed separately for the 7.5 and $15 \mathrm{mg} / \mathrm{kg}$ cocaine reinstatement test sessions using a one-way ANOVA with dose of antagonist as a between-subjects factor. Significant main effects were further analyzed using Dunnet tests to compare dosage groups to the vehicle control group. Trend analyses were also performed when the data varied systematically by dose. To verify reinstatement in controls receiving vehicle, planned paired-sample $t$-tests were conducted to compare responses during a given test session to the respective extinction baseline.

\section{RESULTS}

All descriptive statistics given below are presented as the mean \pm SEM.

\section{Self-Administration Training and Extinction}

Response rates under the VR 5 schedule during the last 5 days of self-administration training averaged $77.1 \pm 8.04$, $77.0 \pm 6.89$, and $80.3 \pm 5.70$ lever presses/h for WAY 100635, ketanserin, and SB 242,084 experiments, respectively. The total number of cocaine infusions delivered during the self-administration phase for WAY 100635, 
ketanserin, and SB 242,084 experiments, respectively, averaged $629.4 \pm 26.7,565.71 \pm 24.6$, and 554.1 \pm 23.80 , and the number of infusions per 2-h session averaged $22.7 \pm 0.94,25.0 \pm 1.03$, and $24.6 \pm 1.02$. Responses/hour on the first day of extinction training for WAY 100635, ketanserin, and SB 242,084 experiments, respectively, averaged $48.4 \pm 6.5,51.3 \pm 4.7$, and $77.3 \pm 7.0$. There were no differences across groups on any of these measures. Furthermore, extinction baseline response rates did not differ across groups in any of the experiments for any of the test days, and are therefore shown averaged across groups to simplify data presentation (see Figures 1 and 2).

\section{Cue Reinstatement}

On all reinstatement test days in this study, responses on the inactive lever were negligible (ie group means $\leqslant 6$ responses/h; data not shown). In each of the three experiments, controls pretreated only with vehicle exhibited an increase in responding relative to their extinction baseline $(t$ 's $(7-12)=2.64-7.07 ; \quad P<0.05)$, indicating that response-contingent cues reinstated extinguished cocaineseeking behavior. The overall ANOVA of responding during cue reinstatement in animals pretreated with WAY 100635 revealed a main effect of $d$-fenfluramine pretreatment $(\mathrm{F}(1,27)=22.68, P<0.001)$, but no effect of dose of WAY 100635 nor an interaction. Thus, WAY 100635 failed to alter cue reinstatement, as well as the $d$-fenfluramine-induced attenuation of cue reinstatement (see Figure 1a). WAY 100635 also failed to alter response latency, whereas $d$-fenfluramine increased response latency $(\mathrm{F}(1,27)=8.17$, $P<0.01$ ) (see Table 1).

The overall ANOVA of responding during cue reinstatement in animals pretreated with ketanserin revealed main effects of ketanserin dose $(\mathrm{F}(4,50)=3.61, P=0.05)$ and $d$-fenfluramine pretreatment $(\mathrm{F}(1,50)=10.30, P<0.005)$, but no interaction. Ketanserin pretreatment dose-dependently decreased cue reinstatement of cocaine-seeking behavior regardless of whether animals received vehicle or $d$-fenfluramine pretreatment (see Figure 1b), with a significant decrease in responding at 3.0 and $10.0 \mathrm{mg} / \mathrm{kg}$ doses relative to vehicle (Dunnet test, $P<0.05$; see inset in Figure 1b). Ketanserin also increased response latency $(\mathrm{F}(4,50)=7.83, P<0.001)$, with post hoc analyses revealing an increase at the $10.0 \mathrm{mg} / \mathrm{kg}$ dose relative to vehicle (Dunnet test, $P<0.001$; see Table 1).

The overall ANOVA of responding during cue reinstatement in animals pretreated with SB 242,084 revealed a main

Figure I Effects of WAY $100635(N=7-8)(a)$, ketanserin $(N=10-13)$ (b), and SB 242,084 (N=11-13) (c) on reinstatement of cocaine-seeking behavior by response-contingent cue presentations. Each animal was tested for cue reinstatement twice, once following pretreatment with their assigned dose of antagonist alone and once following pretreatment with their assigned dose of antagonist and $d$-fenfluramine $(\mathrm{I} \mathrm{mg} / \mathrm{kg}$, i.p.; see Materials and methods for time of injections prior to testing). Cocaineseeking behavior is expressed as mean responses/hour ( \pm SEM). Baseline $(\mathrm{BL})$ response rates were obtained during the extinction session the day prior to testing. The inset in panel (b) displays the main effect of ketanserin dose $(x$-axis) on responses/hour ( $y$-axis) collapsed across $d$-fenfluramine treatment. The asterisks $\left(^{*}\right)$ represent a significant difference from appropriate vehicle control (Dunnet test, $P \leqslant 0.05$ ). effect of $d$-fenfluramine pretreatment $(\mathrm{F}(1,44)=11.54$, $P<0.001)$ and a $d$-fenfluramine pretreatment by $\mathrm{SB}$ 242,084 interaction $(\mathrm{F}(3,44)=3.88, P<0.05)$. To further analyze the interaction, the effects of SB 242,084 with or without $d$-fenfluramine pretreatment were examined using one-way ANOVAs and trend analyses. SB 242,084 alone failed to alter cue reinstatement; however, trend analyses

\section{Cue reinstatement of cocaine-seeking behavior}

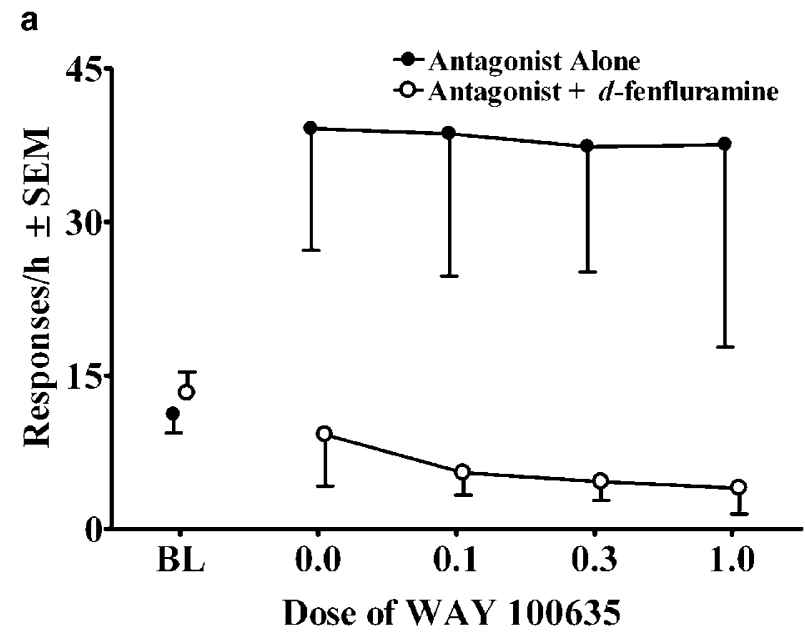

b

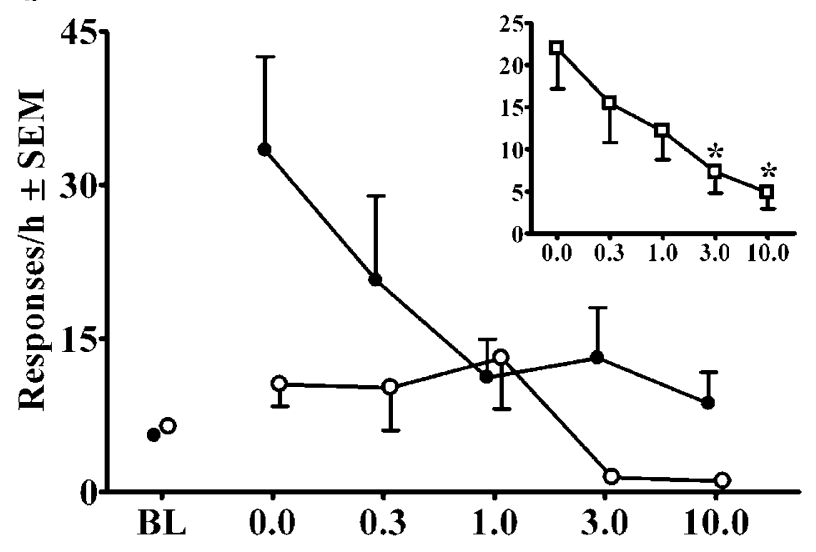

Dose of Ketanserin

c

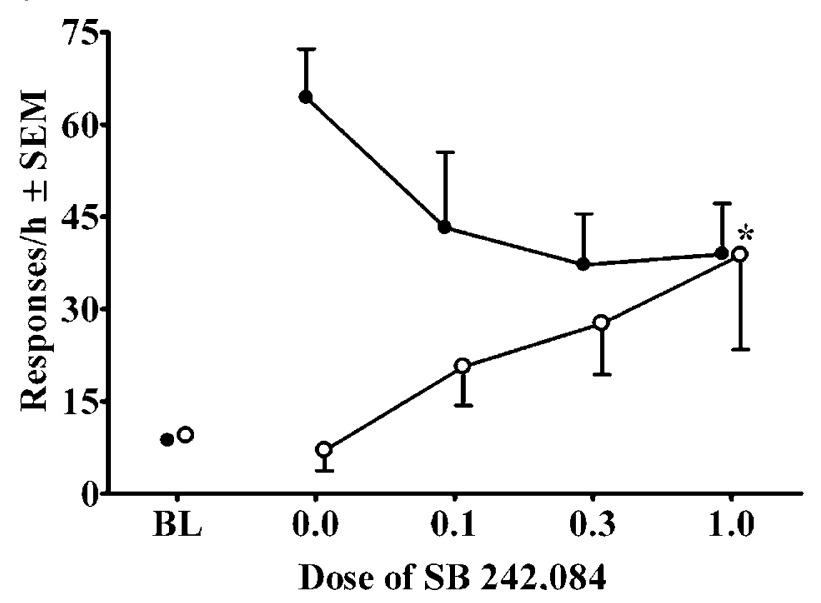


Table I Effects of 5-HT Antagonists with and without d-Fenfluramine ( $d$-fen) Pretreatment on Latency to First Response (Average Min \pm SEM) During Cue Reinstatement Tests

\begin{tabular}{|c|c|c|c|c|c|c|}
\hline \multirow[b]{2}{*}{ Antagonist dose (mg/kg) } & \multicolumn{2}{|c|}{ WAY 100635} & \multicolumn{2}{|c|}{ Ketanserin } & \multicolumn{2}{|c|}{ SB 242,084} \\
\hline & +Vehicle & $+d-f e n *$ & +Vehicle & $+d$-fen & +Vehicle & $+d$-fen \\
\hline 0.1 & $9.2 \pm 7.3$ & $20.5 \pm 10.0$ & & & $3.8 \pm 2.6$ & $5.7 \pm 3.9$ \\
\hline 0.3 & $1.2 \pm 0.7$ & $15.6 \pm 9.7$ & $19.8 \pm 8.9$ & $13.4 \pm 7.4$ & $10.2 \pm 5.6$ & $1.7 \pm 0.8$ \\
\hline 10.0 & & & $39.6 \pm 7.0 * * *$ & $49.6 \pm 7.0 * * *$ & & \\
\hline
\end{tabular}

*Significant difference from vehicle, ANOVA main effect $(P<0.01)$.

** Significant difference from vehicle, Dunnet test $(P<0.00 \mathrm{I})$.

revealed a significant linear trend for SB 242,084 to reverse the $d$-fenfluramine-induced attenuation of cue-elicited responding $(P<0.05)$, with a significant increase observed at the $1.0 \mathrm{mg} / \mathrm{kg}$ dose relative to vehicle (Dunnet test, $P=0.05$; see Figure 1c). SB 242,084 failed to reliably alter response latency (see Table 1 ).

\section{Cocaine Reinstatement}

In each experiment, controls pretreated with vehicle alone exhibited an increase in responding relative to their extinction baseline at both cocaine priming doses ( $t$ 's $s$ $11)=2.58-5.04 ; P<0.05)$, indicating that cocaine priming reinstated extinguished cocaine-seeking behavior. WAY 100635 attenuated cocaine-primed reinstatement of cocaine-seeking behavior $\quad(\mathrm{F}(3,26)=4.59, \quad P<0.05) \quad$ (see Figure 2a). Post hoc analyses indicated a decrease in response rates at the $0.1,0.3$, and $1.0 \mathrm{mg} / \mathrm{kg}$ doses relative to vehicle (Dunnet test, $P \leqslant 0.05$ ). Neither ketanserin nor SB 242,084 significantly altered cocaine-primed reinstatement of cocaine-seeking behavior at either the 7.5 or $15 \mathrm{mg} / \mathrm{kg}$ cocaine priming dose (see Figure $2 b$ and $c$ ).

\section{Locomotor Activity}

The overall ANOVA of locomotor activity revealed no effect of ketanserin dose $(\mathrm{F}(2,16)=0.323, P=0.7)$ (data not shown).

\section{DISCUSSION}

The results revealed differential effects of 5-HT receptor antagonists on cocaine-seeking behavior reinstated by cues $v s$ cocaine priming. The $5-\mathrm{HT}_{1 \mathrm{~A}}$ receptor antagonist, WAY 100635, failed to alter reinstatement of cocaine-seeking behavior by response-contingent cocaine-paired cues, but attenuated cocaine-primed reinstatement. Conversely, the $5-\mathrm{HT}_{2 \mathrm{~A} / \mathrm{C}}$ receptor antagonist, ketanserin, attenuated reinstatement of cocaine-seeking behavior by responsecontingent cocaine-paired cues, but failed to alter cocaineprimed reinstatement. The selective $5-\mathrm{HT}_{2 \mathrm{C}}$ receptor antagonist, SB 242,084, failed to alter either cue or cocaine-primed reinstatement when administered alone, but was the only drug that reversed the $d$-fenfluramineinduced attenuation of cue reinstatement.

The findings suggest that $5-\mathrm{HT}_{1 \mathrm{~A}}$ receptors are not involved in cue reinstatement, but are critical for mediating cocaine-primed reinstatement. The results are consistent with previous studies demonstrating that WAY 100635 attenuates cocaine-primed reinstatement (Schenk, 2000), but fails to alter reinstatement by a discriminative cue previously associated with cocaine availability (Cervo et al, 2003). The demonstration of differential effects of WAY 100635 on cue $v s$ cocaine-primed reinstatement in the same animals in the present study offers strong evidence that the effects of WAY 100635 are selective for cocaine-seeking behavior elicited by cocaine priming. Furthermore, since the effective doses of WAY 100635 did not alter responding or response latency during cue reinstatement tests, the decrease in cocaine-primed reinstatement is not simply due to a general disruption of operant behavior. The selective decrease in cocaine-primed reinstatement suggests that WAY 100635 specifically attenuates the incentive motivational effects of cocaine priming. It is unlikely that WAY 100635 attenuates cocaine-primed reinstatement by altering the discriminative stimulus effects of the cocaine prime since $5-\mathrm{HT}_{1 \mathrm{~A}}$ receptors do not play a critical role in these effects (Przegalinski and Filip, 1997; De La Garza et al, 1998). However, it remains unclear whether WAY 100635 directly alters motivation or some other process, such as reduction of anxiety (Cao and Rodgers, 1997; Griebel et al, 2000) or stimulant effects of cocaine (Carey et al, 2001), which may indirectly influence motivation. It is also unclear whether the effects of WAY 100635 are due to blockade of postsynaptic $5-\mathrm{HT}_{1 \mathrm{~A}}$ receptors or to an increase in extracellular 5-HT levels via blockade of somatodendritic $5-\mathrm{HT}_{1 \mathrm{~A}}$ autoreceptors. Indeed, WAY 100635 has been shown to attenuate cocaine-induced locomotor activity while increasing extracellular 5-HT, but not dopamine, in the nucleus accumbens and hippocampus (Muller et al, 2002a,b). Thus, a WAY 100635-induced increase in extracellular 5-HT in cocaine-primed animals by blockade of $5-\mathrm{HT}_{1 \mathrm{~A}}$ autoreceptors may mediate the attenuation of cocaine-primed reinstatement via enhanced stimulation of $5-\mathrm{HT}$ receptors other than the $5-\mathrm{HT}_{1 \mathrm{~A}}$ subtype.

In contrast to the evidence for a role of $5-\mathrm{HT}_{1 \mathrm{~A}}$ receptors in cocaine reinstatement, the present study failed to find 


\section{Cocaine reinstatement of cocaine-seeking behavior}

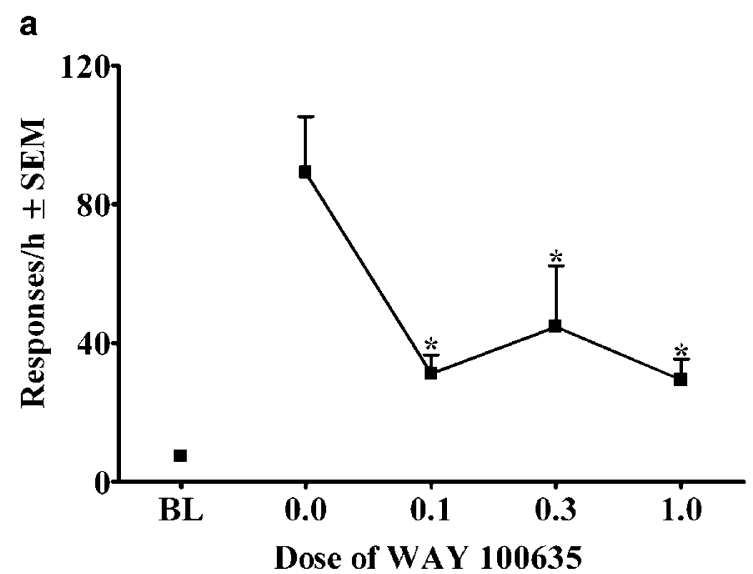

b

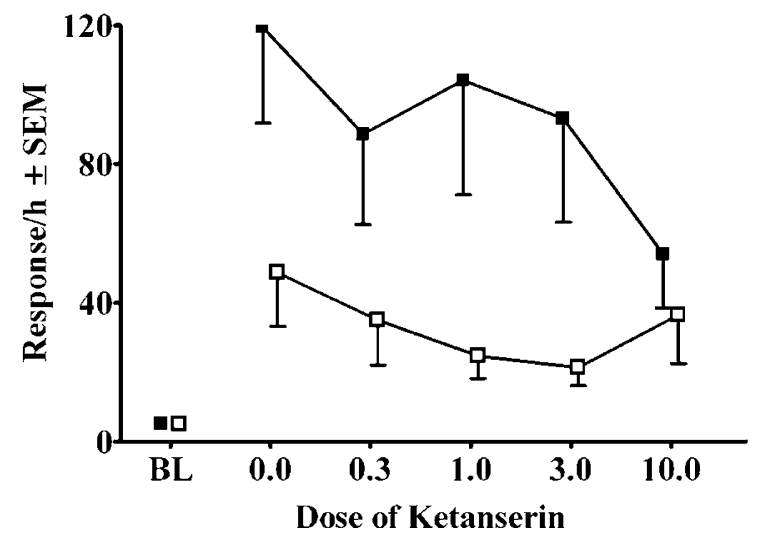

C

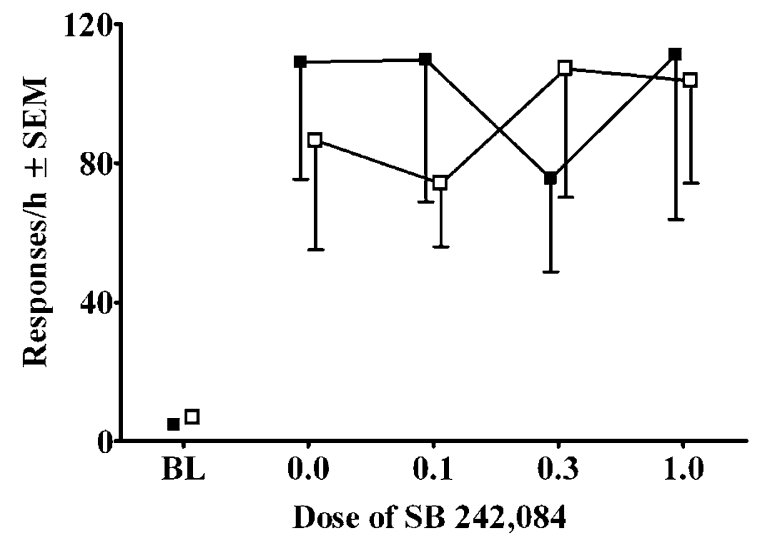

Figure 2 Effects of WAY $100635(N=7-8)(a)$, ketanserin $(N=8-12)$ (b), and SB 242,084 ( $N=8-9)$ (c) on reinstatement of cocaine-seeking behavior by i.p. cocaine priming doses of either $7.5 \mathrm{mg} / \mathrm{kg}(\square)$ or $15.0 \mathrm{mg} /$ $\mathrm{kg}(\boldsymbol{\square})$. Cocaine-seeking behavior is expressed as mean responses/hour $( \pm$ SEM). Animals in the ketanserin experiment received the $15 \mathrm{mg} / \mathrm{kg}$ prime prior to their first test and the $7.5 \mathrm{mg} / \mathrm{kg}$ prime prior to their second test, whereas animals in the SB 242,084 experiment received the $7.5 \mathrm{mg} / \mathrm{kg}$ prime prior to their first test and the $15 \mathrm{mg} / \mathrm{kg}$ prime prior to the second test (see Materials and methods for rationale for order of tests). Baseline $(\mathrm{BL})$ response rates were obtained during the extinction session the day prior to testing and animals received a saline prime immediately before the extinction baseline session. Asterisks (*) represent a significant difference from vehicle (Dunnet test, $P \leqslant 0.05$ ). evidence for a role of $5-\mathrm{HT}_{2 \mathrm{C}}$ receptors in cocaine-primed reinstatement. The finding that the $5-\mathrm{HT}_{2 \mathrm{C}}$-selective antagonist, SB 242,084, failed to alter cocaine-primed reinstatement was surprising given that previous research has shown this drug enhances reinstatement after a $10 \mathrm{mg} /$ $\mathrm{kg}$, i.p. cocaine prime (Fletcher et al, 2002a). Furthermore, the 5- $\mathrm{HT}_{2 \mathrm{C}}$ agonist, Ro 60-0175, attenuates cocaine-primed reinstatement (Grottick et al, 2000), providing further evidence for a role of $5-\mathrm{HT}_{2 \mathrm{C}}$ receptors in this behavior. SB 242,084 likely enhances cocaine-primed reinstatement by enhancing dopamine neurotransmission since previous research has shown that $5-\mathrm{HT}_{2 \mathrm{C}}$ receptors inhibit mesocorticolimbic dopamine release (Di Giovanni et al, 1999; Di Matteo et al, 1999, 2000a, b), which is thought to play a role in cocaine-primed reinstatement of cocaine-seeking behavior (Weissenborn et al, 1996; Khroyan et al, 2000; Alleweireldt et al, 2002). The reason for the discrepancy in the effects of SB 242,084 on cocaine reinstatement across studies is unclear, but may be due to differences in cocaine priming and/or SB 242,084 doses tested. In the present study, we first examined the effects of a relatively low cocaine priming dose $(7.5 \mathrm{mg} / \mathrm{kg}$, i.p.) to allow for sensitivity to detect the predicted SB 242,084-induced increase in the effectiveness of the cocaine prime. However, animals in this experiment exhibited a more robust reinstatement at the $7.5 \mathrm{mg} / \mathrm{kg}$ priming dose than expected, and response rates were similar to that observed on the subsequent test with the $15 \mathrm{mg} / \mathrm{kg}$ priming dose. Therefore, we may not have detected enhancement by SB 242,084 due to a ceiling effect (see Figure 2c).

The finding that the $5-\mathrm{HT}_{2 \mathrm{~A} / \mathrm{C}}$ antagonist, ketanserin, failed to alter cocaine-primed reinstatement was not surprising given that previous research has shown that the general $5-\mathrm{HT}_{2}$ receptor antagonist, ritanserin, has no effect on this behavior (Schenk, 2000). Furthermore, Fletcher et al (2002a) have reported opposing actions of $5-\mathrm{HT}_{2 \mathrm{~A}}$ and $5-\mathrm{HT}_{2 \mathrm{C}}$ antagonists on cocaine-primed reinstatement of cocaine-seeking behavior, with the 5- $\mathrm{HT}_{2 \mathrm{~A}}$ receptor antagonist, MDL 100907, attenuating and the $5-\mathrm{HT}_{2 \mathrm{C}}$ antagonist, SB 242,084, facilitating this behavior. This finding suggests that the competition between effects produced by antagonism of $5-\mathrm{HT}_{2 \mathrm{~A}}$ and $5-\mathrm{HT}_{2 \mathrm{C}}$ receptors following ketanserin likely results in mutual reversal such that no net effect is observed.

Ketanserin attenuated cue reinstatement of cocaineseeking behavior, whereas SB 242,084 had no effect on cue reinstatement when given alone. The effect of ketanserin was selective for reinstatement by response-contingent cue since there was no significant effect of ketanserin on cocaine-primed reinstatement. This finding suggests that the ketanserin-induced attenuation of cue reinstatement was not due to general disruption of operant behavior. The finding that ketanserin did not alter locomotor activity is consistent with previous research (McMahon and Cunningham, 2001b) and further suggests that the effect of ketanserin on cue reinstatement was not due to disruption of motor function. Ketanserin likely attenuated the conditioned reinforcing effects of the response-contingent cues, consistent with previous research demonstrating that ketanserin suppresses responding for other conditioned reinforcers (Fletcher et al, 2002b). The finding that SB 242,084 had no effect suggests that decreasing stimulation 
of $5-\mathrm{HT}_{2 \mathrm{C}}$ receptors alone does not attenuate cue reinstatement. Therefore, the effect of ketanserin may result from its action of blocking $5-\mathrm{HT}_{2 \mathrm{~A}}$ receptors, an action that may predominate given that ketanserin has a higher affinity for $5-\mathrm{HT}_{2 \mathrm{~A}}$ receptors relative to $5-\mathrm{HT}_{2 \mathrm{C}}$ and $5-\mathrm{HT}_{2 \mathrm{~B}}$ receptor subtypes $\left(\mathrm{p} K_{\mathrm{i}}=8.9,7.0\right.$, and 5.4, respectively; Baxter et al, 1995). Alternatively, it is possible that $\alpha$-adrenergic receptors may be involved in the attenuation of cue reinstatement since ketanserin also has affinity for these receptors $\left(\mathrm{p} K_{\mathrm{i}}=8.0,8.3\right.$, and 7.6 for $\alpha-1 \mathrm{a}, 1 \mathrm{~b}$, and $1 \mathrm{c}$, respectively; Israilova et al, 2002). Further research is needed to investigate these possibilities. However, if the effect of ketanserin on cue reinstatement is $5-\mathrm{HT}_{2 \mathrm{~A}}$ receptor mediated, this would suggest that stimulation of $5-\mathrm{HT}_{2 \mathrm{~A}}$ receptors may facilitate cue reinstatement of cocaineseeking behavior, similar to that suggested for cocaineprimed reinstatement (Fletcher et al, 2002a).

Consistent with our previous research (Burmeister et al, 2003), $d$-fenfluramine attenuated cue reinstatement, and this effect was reversed by SB 242,084. Previous research has shown that SB 242,084 does not alter basal locomotor activity (Fletcher et al, 2002b), but does potentiate $d$-fenfluramine-induced hyperactivity (Higgins et al, 2001). However, it is unlikely that the reversal of $d$-fenfluramine-induced attenuation of cue reinstatement is due to an increase in locomotor activity since response latency did not differ across tests with $d$-fenfluramine alone vs coadministration with SB 242,084 (see Table 1). Furthermore, these findings are consistent with a recent report that SB 242,084 reverses the attenuating effects of 3,4-methylenedioxymethamphetamine (MDMA) on responding for a conditioned reinforcer (Fletcher et al, 2002b). MDMA is an amphetamine derivative that produces greater release of 5-HT relative to dopamine (Rothman et al, 2001). It is likely that MDMA-induced suppression of responding for a conditioned reinforcer is due to enhanced 5-HT since 5 -HT indirect agonist suppress, and dopamine indirect agonist enhance, responding for conditioned reinforcers (Robbins et al, 1983; Fletcher, 1995). Furthermore, the SB 242,084 -induced reversal of this effect suggests it is mediated via increased stimulation of $5-\mathrm{HT}_{2 \mathrm{C}}$ receptors. The $d$-fenfluramine-induced attenuation of cue reinstatement is also likely mediated by an increase in $5-\mathrm{HT}_{2 \mathrm{C}}$ receptor stimulation via increased 5-HT release (Rowland and Carlton, 1986; Leferrere and Wurtman, 1989), as well as direct $5-\mathrm{HT}_{2 \mathrm{C}}$ agonist actions of the parent compound and its active metabolite (Curzon et al, 1997; Rothman and Baumann, 2002) since the effect is reversed by SB 242,084 . This finding suggests that increased stimulation of $5-\mathrm{HT}_{2 \mathrm{C}}$ receptors inhibits cue reinstatement of cocaine-seeking behavior.

In contrast to the effect of SB 242,084, ketanserin appeared to exacerbate the inhibitory effect of $d$-fenfluramine on cue reinstatement. The latter effect may involve an action of ketanserin at $5-\mathrm{HT}_{2 \mathrm{~A}}$ receptors or $\alpha$-adrenergic receptors given the pharmacology of this drug discussed above. Although further pharmacological investigation is needed to determine which of these mechanisms is involved, given the opposing roles of $5-\mathrm{HT}_{2 \mathrm{~A}}$ and $5-\mathrm{HT}_{2 \mathrm{C}}$ receptors in other psychostimulant-related behaviors (McMahon et al, 2001; McMahon and Cunningham 2001a; Fletcher et al, 2002a), it seems likely that ketanserin further decreased cue reinstatement of cocaine-seeking behavior by blocking $5-\mathrm{HT}_{2 \mathrm{~A}}$ receptors. If this hypothesis is correct, then decreased stimulation of $5-\mathrm{HT}_{2 \mathrm{~A}}$ receptors may inhibit cue reinstatement of cocaine-seeking behavior.

In conclusion, the results of this study suggest that stimulation of $5-\mathrm{HT}_{1 \mathrm{~A}}$ receptors plays a critical role in cocaine-primed reinstatement, but not cue reinstatement. Furthermore, increasing stimulation of $5-\mathrm{HT}_{2 \mathrm{C}}$ receptors inhibits cue reinstatement of cocaine-seeking behavior and we hypothesize that decreasing stimulation of $5-\mathrm{HT}_{2 \mathrm{~A}}$ receptors may also inhibit this behavior. Further research is needed to determine whether the drug interactions observed in this study involve the hypothesized receptor systems and/or whether the drugs alter each others bioavailability. In addition, research examining chronic administration of the 5-HT receptor antagonists is needed to investigate possible clinical applications for the treatment of cocaine dependence. Importantly, the differential effects of $5-\mathrm{HT}_{1 \mathrm{~A}}$ receptor antagonism on cue $v s$ cocaine-primed reinstatement suggest that different interventions may be needed for decreasing incentive motivational effects of these stimuli.

\section{ACKNOWLEDGEMENTS}

The authors thank Arturo Zavala, Adam Taylor, and Dr Brock Schroeder for their expert technical assistance, and Arturo Zavala and Andrea Alleweireldt for their comments on a previous version of this manuscript. This research was supported by a grant from NIDA, DA11064, and the Howard Hughes Medical Institute through the Undergraduate Biology Enrichment Program.

\section{REFERENCES}

Alleweireldt AT, Weber SM, Kirschner KF, Bullock BL, Neisewander JL (2002). Blockade or stimulation of $D_{1}$ dopamine receptors attenuates cue reinstatement of extinguished cocaine-seeking behavior in rats. Psychopharmacology 159: 285-293.

Baker DA, Tran-Nguyen LTL, Fuchs RA, Neisewander JL (2001). Influence of individual differences and chronic fluoxetine treatment on cocaine-seeking behavior in rats. Psychopharmacology 155: 18-26.

Baxter G, Kennett G, Blaney F, Blackburn T (1995). 5- $\mathrm{HT}_{2}$ receptor subtypes: a family re-united? Trend Pharmacol Sci 16: 105-110.

Burmeister JJ, Lungren EM, Neisewander JL (2003). Effects of fluoxetine and $d$-fenfluramine on cocaine-seeking behavior in rats. Psychopharmacology 168: 146-154.

Cao BJ, Rodgers RJ (1997). Influence of 5- $\mathrm{HT}_{1 \mathrm{~A}}$ receptor antagonism on plus-maze behaviour in mice. II. WAY 100635 , SDZ 216-525 and NAN-190. Pharmacol Biochem Behav 58: 593-603.

Carey RJ, DePalma G, Damianopoulos E (2001). Cocaine and serotonin: a role for the $5-\mathrm{HT}_{1 \mathrm{~A}}$ receptor site in the mediation of cocaine stimulant effects. Behav Brain Res 126: 127-133.

Carroll ME, France CP, Meisch RA (1981). Intravenous selfadministration of etonitazene, cocaine and phencyclidine in rats during food deprivation and satiation. J Pharmacol Exp Ther 217: 241-247.

Cervo L, Carnovali F, Stark JA, Mennini T (2003). Cocaine-seeking behavior in response to drug-associated stimuli in rats: involvement of $\mathrm{D}_{3}$ and $\mathrm{D}_{2}$ dopamine receptors. Neuropsychopharmacology 28: 1150-1159. 
Curzon G, Gibson EL, Oluyomi AO (1997). Appetite suppression by commonly used drugs depends on 5-HT receptors but not on 5-HT availability. Trend Pharmacol Sci 18: 21-25.

De La Garza II R, Callahan Pm, Cunningham KA (1998). The discriminative stimulus properties of cocaine, a $5-\mathrm{HT}_{1 \mathrm{~A}}$ agonist or antagonist, into the ventral tegmental area. Psychopharmacology 137: 1-6.

de Wit H, Stewart J (1981). Reinstatement of cocaine-reinforced responding in the rat. Psychopharmacology 75: 134-143.

Di Giovanni G, De Deurwaerdere P, Di Mascio M, Di Matteo V, Esposito E, Spampinato U (1999). Selective blockade of serotonin-2C/2B receptors enhances mesolimbic and mesostriatal dopaminergic function: a combined in vivo electrophysiology and microdialysis study. Neuroscience 91: 587-597.

Di Matteo V, Di Mascio M, Di Giovanni G, Esposito E (1999). SB 242084 , a selective serotonin ${ }_{2 C}$ receptor antagonist, increases dopaminergic transmission in the mesolimbic system. Neuropharmacology 38: 1195-1205.

Di Matteo V, Di Mascio M, Di Giovanni G, Esposito E (2000a). Acute administration of amitriptyline and mianserin increases dopamine release in the rat nucleus accumbens: possible involvement of serotonin ${ }_{2 C}$ receptors. Psychopharmacology 150: $45-51$.

Di Matteo V, Di Mascio M, Di Giovanni G, Esposito E (2000b). Biochemical and electrophysiological evidence that RO 60-0175 inhibits mesolimbic dopaminergic function through serotonin ${ }_{2 \mathrm{C}}$ receptors. Brain Res 865: 85-90.

Ehrman RN, Robbins SJ, Childress AR, O'Brien CP (1992). Conditioned responses to cocaine-related stimuli in cocaine abuse patients. Psychopharmacology 107: 523-529.

Fletcher PJ (1995). Effects of $d$-fenfluramine and metergoline on responding for conditioned reward and the response potentiating effect of nucleus accumbens $d$-amphetamine. Psychopharmacology 118: 155-163.

Fletcher PJ, Grottick AJ, Higgins GA (2002a). Differential effects of the $5-\mathrm{HT}_{2 \mathrm{~A}}$ receptor antagonist $\mathrm{M} 100,907$ and the $5-\mathrm{HT}_{2 \mathrm{C}}$ receptor antagonist SB242,084 on cocaine-induced locomotor activity, cocaine self-administration and cocaine-induced reinstatement of responding. Neuropsychopharmacology 27: 576-586.

Fletcher PJ, Korth KM, Robinson SR, Baker GB (2002b). Multiple 5 -HT receptors are involved in the effects of acute MDMA treatment: studies on locomotor activity and responding for conditioned reinforcement. Psychopharmacology 162: 282-291.

Fuchs RA, Tran-Nguyen LTL, Specio SE, Groff RS, Neisewander JL (1998). Predictive validity of the extinction/reinstatement model of drug craving. Psychopharmacology 135: 151-160.

Griebel G, Rodgers RJ, Perrault G, Sanger DJ (2000). The effects of compounds varying in selectivity as $5-\mathrm{HT}_{1 \mathrm{~A}}$ receptor antagonists in three rat models of anxiety. Neuropharmacology 39: 1848-1857.

Grottick AJ, Fletcher PJ, Higgins GA (2000). Studies to investigate the role of $5-\mathrm{HT}_{2 \mathrm{C}}$ receptors on cocaine- and food-maintained behavior. J Pharmacol Exp Ther 295: 1183-1191.

Higgins GA, Ouagazzal AM, Grottick AJ (2001). Influence of the $5-\mathrm{HT}_{2 \mathrm{C}}$ receptor antagonist SB 242,084 on behaviour produced by the $5-\mathrm{HT}_{2}$ agonist Ro 60-0175 and the indirect 5-HT agonist dexfenfluramine. Br J Pharmacol 133: 459-466.

Israilova $\mathrm{M}$, Suzuki $\mathrm{F}$, Tanaka T, Nagatomo T, Taniguchi T, Muramatsu I (2002). Binding and functional affinity of sarpogrelate, its metabolite $\mathrm{m}-1$ and ketanserin for human recombinant alpha-1-adrenoceptor subtypes. Pharmacology 65: 69-73.

Jaffe JH, Cascella NG, Kumor KM, Sherer MA (1989). Cocaineinduced cocaine craving. Psychopharmacology 97: 59-64.

Khroyan TV, Barrett-Larimore RL, Rowlett JK, Apealman RD (2000). Dopamine $\mathrm{D}_{1}$ - and $\mathrm{D}_{1}$-like receptor mechanisms in relapse to cocaine-seeking behavior: effects of selective antagonists and agonists. J Pharmacol Exp Ther 294: 680-687.

Leferrere B, Wurtman RJ (1989). Effect of D-fenfluramine on serotonin release in brains of anaesthetized rats. Brain Res 504: 258-263.

Markou A, Weiss F, Gold LH, Caine SB, Schulteis G, Koob GF (1993). Animal models of drug craving. Psychopharmacology 112: $163-182$.

McMahon LR, Cunningham KA (2001a). Role of 5- $\mathrm{HT}_{2 \mathrm{~A}}$ and $5-\mathrm{HT}_{2 \mathrm{~B} / 2 \mathrm{C}}$ receptors in the behavioral interactions between serotonin and catecholamine reuptake inhibitors. Neuropsychopharmacology 24: 319-329.

McMahon LR, Cunningham KA (2001b). Antagonism of 5-hydroxytryptamine $\mathrm{2}_{\mathrm{A}}$ receptors attenuates the behavioral effects of cocaine in rats. J Pharmacol Exp Ther 297: 357-363.

McMahon LR, Filip M, Cunningham KA (2001). Differential regulation of the mesoaccumbens circuit by serotonin $5-\mathrm{HT}_{2 \mathrm{~A}}$ and $5-\mathrm{HT}_{2 \mathrm{C}}$ receptors. J Neurosci 21: 7781-7787.

Muller CP, Carey RJ, De Souza Silva MA, Jocham G, Huston JP (2002a). Cocaine increases serotonergic activity in hippocampus and nucleus accumbens in vivo: $5-\mathrm{HT}_{1 \mathrm{~A}}$-receptor antagonism blocks behavioral but potentiates sertonergic activation. Synapse 45: 67-77.

Muller CP, De Souza Silva MA, DePalma G, Tomaz C, Carey RJ, Huston JP (2002b). The selective serotonin(1A)-receptor antagonist WAY 100635 blocks behavioral stimulating effects of cocaine but not ventral striatal dopamine increase. Behav Brain Res 134: 337-346.

Munzar P, Justinova Z, Kutkat SW, Goldberg SR (2002). Differential involvement of $5-\mathrm{HT}_{2 \mathrm{~A}}$ receptors in the discriminative-stimulus effects of cocaine and methamphetamine. Eur $J$ Pharmacol 436: 75-82.

Neisewander JL, Baker DA, Fuchs RA, Tran-Nguyen LTL, Palmer A, Marshall JF (2000). Fos protein expression and cocaineseeking behavior in rats after exposure to a cocaine selfadministration environment. J Neurosci 20: 798-805.

Przegalinski E, Filip M (1997). Stimulation of serotonin (5-HT) $1 \mathrm{~A}$ receptors attenuates the locomotor, but not the discriminative, effects of amphetamine and cocaine in rats. Behav Pharmacol 8: 699-706.

Robbins TW, Watson BA, Gaskin M, Ennis C (1983). Contrasting interactions of pipradrol, $d$-amphetamine, cocaine, cocaine analogues, apomorphine and other drugs with conditioned reinforcement. Psychopharmacology 80: 113-119.

Robinson TE, Berridge KC (1993). The neural basis of drug craving: an incentive-sensitization theory of addiction. Brain Res Rev 18: 247-291.

Rohsenow DJ, Childress AR, Monti PM, Niaura RS, Abrams DB (1991). Cue reactivity in addictive behaviors: theoretical and treatment implication. Int J Addict 25: 957-993.

Rothman RB, Baumann MH (2002). Serotonin releasing agents: neurochemical, therapeutic and adverse effects. Pharmacol Biochem Behav 71: 825-836.

Rothman RB, Bauman MH, Dersch CM, Romero DV, Rice KC, Carroll FI et al (2001). Amphetamine-type central nervous system stimulants release norepinephrine more potently than they release dopamine and serotonin. Synapse 39: $32-41$.

Rowland NE, Carlton J (1986). Neurobiology of an anorectic drug: fenfluramine. Prog Neurobiol 27: 13-62.

Schenk S (2000). Effects of the serotonin 5- $\mathrm{HT}_{2}$ antagonist, ritanserin, and the serotonin $5-\mathrm{HT}_{1 \mathrm{~A}}$ antagonist, WAY 100635, on cocaine-seeking behavior in rats. Pharmacol Biochem Behav 67: $363-369$.

Stewart J (1983). Conditioned and unconditioned drug effects in relapse to opiate and stimulant drug self-administration. Prog Neuropsychopharmacol Biol Psychiatry 7: 591-597. 
Tran-Nguyen LTL, Baker DA, Grote KA, Solano J, Neisewander JL (1999). Serotonin depletion attenuates cocaine-seeking behavior in rats. Psychopharmacology 146: 60-66.

Tran-Nguyen LTL, Bellew JG, Grote KA, Neisewander JL (2001). Serotonin depletion attenuates cocaine seeking but enhances sucrose seeking and the effects of cocaine priming on reinstatement of cocaine seeking in rats. Psychopharmacology 157: 340-348.
Wallace BC (1989). Psychological and environmental determinants of relapse in crack cocaine smokers. J Subst Abuse Treat 6: 95-106.

Weissenborn R, Deroche V, Koob GF, Weiss F (1996). Effects of dopamine agonists and antagonists on cocaine-induced operant responding for a cocaine-associated stimulus. Psychopharmacology 126: 311-322. 